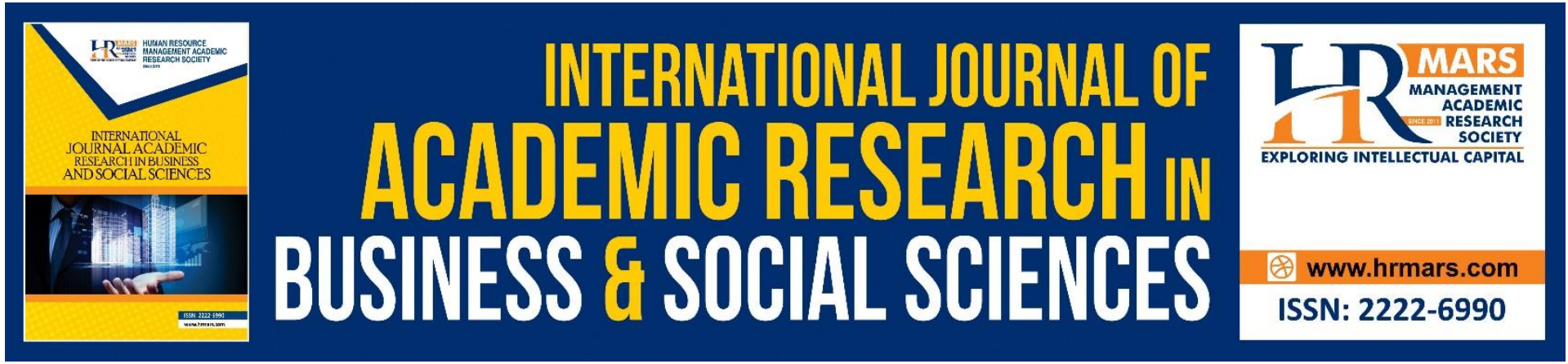

\title{
Dividend Payout Determinants: Evidence of Healthcare Companies in Malaysia
}

\section{Ruziah A. Latif, Syafiqah Jalil and Zuraidah Ahmad}

To Link this Article: http://dx.doi.org/10.6007/IJARBSS/v11-i8/10734

DOI:10.6007/IJARBSS/v11-i8/10734

Received: 18 June 2021, Revised: 16 July 2021, Accepted: 01 August 2021

Published Online: 14 August 2021

In-Text Citation: (Latif et al., 2021)

To Cite this Article: Latif, R. A., Jalil, S., \& Ahmad, Z. (2021). Dividend Payout Determinants: Evidence of Healthcare Companies in Malaysia. International Journal of Academic Research in Business and Social Sciences, 11(8), 317-329.

\section{Copyright: (c) 2021 The Author(s)}

Published by Human Resource Management Academic Research Society (www.hrmars.com)

This article is published under the Creative Commons Attribution (CC BY 4.0) license. Anyone may reproduce, distribute, translate and create derivative works of this article (for both commercial and non-commercial purposes), subject to full attribution to the original publication and authors. The full terms of this license may be seen at: http://creativecommons.org/licences/by/4.0/legalcode

Vol. 11, No. 8, 2021, Pg. 317 - 329

Full Terms \& Conditions of access and use can be found at http://hrmars.com/index.php/pages/detail/publication-ethics 


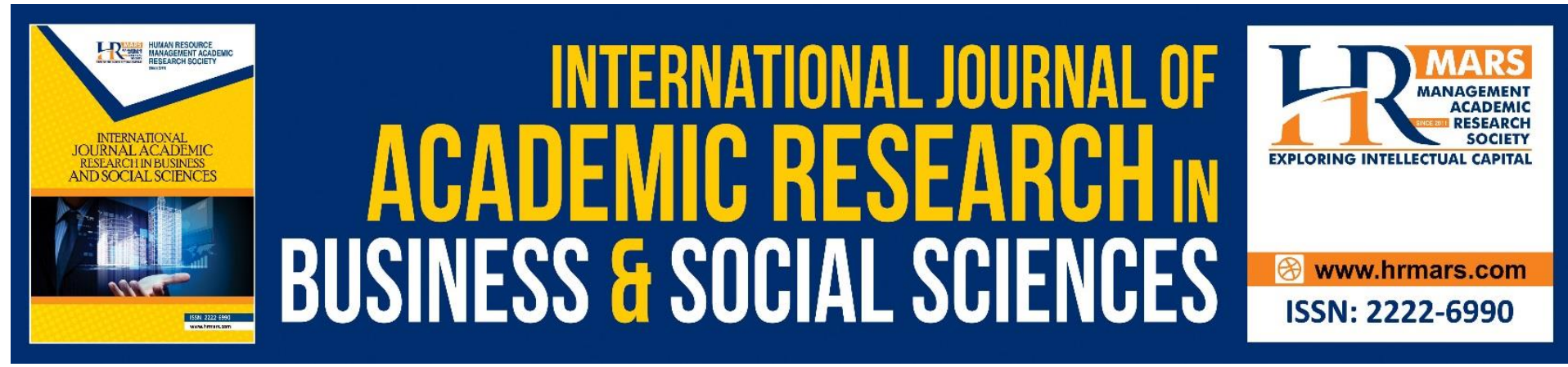

\title{
Dividend Payout Determinants: Evidence of Healthcare Companies in Malaysia
}

\author{
Ruziah A. Latif, Syafiqah Jalil and Zuraidah Ahmad \\ Universiti Teknologi MARA Malaysia
}

\begin{abstract}
The study of what influences the dividend payout policy remains highly relevant as it is an important factor that is being considered by both companies and investors. This study attempts to investigate the significant factors that affect the dividend payout of healthcare companies in Malaysia. To meet the objective of this study, 10 years financial data from a sample of healthcare companies listed on the main board of Bursa Malaysia is analysed to investigate the effect of the determinants towards the dividend payout ratio. Correlation analysis and multiple linear regression analysis are applied to determine the relationship between variables and the effect of the independent variables towards the dividend payout. The findings indicate that liquidity, investment opportunity, leverage and company size are significant in determining the dividend payout ratio of Malaysia healthcare companies.
\end{abstract}

Keywords: Dividend Payout, Dividend Policy, Emerging Market, Healthcare Sector, Corporate Finance

\section{Introduction}

The dividend payout is the portion of the company's earnings that is distributed to the company's shareholders. While the undistributed portion of earnings is known as retained earnings and are used to fund business growth. The dividend payout policy has been one of a crucial finance issue that companies must manage efficiently to secure adequate internal funds for business expansion and at the same time pleasing their shareholders with dividend payments. In addition, the dividend payments also has a function to attract potential investors' interest to the company. Hence, it is a policy which both investors and companies' stakeholders will need to take into consideration before resolving on any decision. Despite its important, dividend policy has still been considered as the unsolved puzzle in the world of academia. There are some issues which appear to be unsolved regarding dividend policy. For instance, what determine the dividend payout? There is still no uniform findings on the determinants of the dividend payout.

There are many contradictory theories of dividends which can be identified. Among the top theories are Modigliani-Miller's dividend irrelevancy theory. According to Miller and Modigliani (1961) dividends are irrelevant factor in determining firm value in a "perfect" market. Based on their model, the value of a firm is determined by investment policy rather than the distribution of cash dividends to shareholders. Therefore, investors would be 
indifferent to any viable dividend policy implemented by companies. On the other hand, Lintner (1965); Gordon (1959) developed the bird-in-the-hand theory which considers dividend as a main determining factor of firm value. The theory claims that investors prefer to receive dividends today rather than to receive capital gains later. Another major theory concerning dividend policy is the tax preference theory. Because the capital gain tax rate is typically lower than the dividend tax rate, this theory argues that investors prefer to invest in lower dividend or even zero payout companies.

The study of what influences the dividend payout policy remains highly relevant as it is an important factor that is being considered by potential investors and as a reflection of companies' performance (Afza and Nazir, 2008). Many studies have addressed this issue in developed equity markets such as in the United States (Farre-Mensa et al., 2014; DeAngelo et al., 2004) and Japan stock markets (Kasahara and Orihara, 2021; Suji, 2010) as well as in emerging markets (Danila et al., 2020; Al Sawaqa, 2021; Manneh and Naser; 2015; Dewasiri et al., 2019). However, most previous research done in the context of the Malaysian market focused on the entire market sectors (Yusof and Ismail, 2016; Khan, 2020) or across several sectors (Issa, 2015). This study focuses on the Malaysia healthcare sector. Recently, due to the COVID-19 outbreak, world economics had been affected including the healthcare sector. The interest of investors in this sector has grown markedly due to the huge business opportunities that have arisen because of the pandemic. Therefore, it is noteworthy to acknowledge the factors influencing the healthcare companies' dividend payout in an emerging market like Malaysia.

This study attempts to investigate the effect of independent variables namely, liquidity, investment opportunity, profitability, leverage and company size on the dependent variable which is dividend payout ratio. The study provides useful references for investors and companies' stakeholders to understand the factors that influence the dividend payout.

\section{Literature Review \\ Dividend Policy}

Previous study on dividend policy has produced a significant amount of literature in this field. However, as mentioned before, it has still been a debatable topic in corporate finance. A dividend policy is the policy a company uses to structure its dividend payout to shareholders. The dividend payout ratio (DPR) is the ratio of the total amount of dividends paid out to shareholders relative to the net income of the company. According to Fitri et al. (2016), although companies should have to finance any capital structure changes and increase growth, companies also have a commitment to enhance shareholders' wealth with the distribution of dividends to shareholders. Many previous studies have used DPR to measure dividend as a dependent variable in dividend policy study (Khan, 2020; Kaźmierska-Jóźwiaka' 2015; Widyasti and Putri, 2021; Mehta, 2012). There are also other measures used in previous studies for dividend policy, for instance, dividend per share (DPS) (Imran, 2015; Trang, 2012; Jaara et al., 2018). However, in this study, DPR is used as the dependant variable.

A number of factors have been identified and discussed in the literature as potential determinants of a company's dividend payout decisions. In this study, the set of following independent variables has been selected: liquidity, investment opportunity, profitability, leverage and company size. 


\section{Dividend Payout and Liquidity}

Previous studies have reported that companies with higher liquidity are most likely to disburse higher dividend payments (Setiawan and Rahmawati, 2020; Ho, 2003). According to Maldajian and El Khoury (2014) a company with liquid assets can generate sufficient and stable cash flows which would then increase its ability to pay dividends to shareholders. Based on previous studies in the context of Malaysia, Yong and Mustapha (2016) and Ong et.al (2018) show that current ratio is a significant variable to determine the companies' DPR. In addition, Malik (2013) asserts that there is a positive relationship between the liquidity and the dividend payout ratio of listed companies on the Karachi stock exchange. Recently, Mazengo and Mwaifyusi (2021), find that liquidity is one of the main determinants of financial institutions' dividend policy. Mehar (2002), however, reports a negative relationship between liquidity and dividend payout from his study of companies on the Karachi Stock Exchange in Pakistan. This is supported by Banarjee (2017); Khan and Ahmad (2017) who also find that a liquidity has a significant negative relationship with dividend policy. Meanwhile, Widyasti and Putri (2021), using a sample of 55 manufacturing companies listed on the Indonesia Stock Exchange for the 2017-2019 argue that liquidity is not a significant dividend policy determinant. Chakraborty et. al (2018); Hashim (2017) also report that liquidity has no effect on companies' DPR. Since there is no consensus on the direction of the association between liquidity and dividend payout, this study will test whether the dividend payout of healthcare companies in Malaysia is affected by liquidity. From that the following hypothesis is proposed: H1: Liquidity has a significant effect on dividend payout.

\section{Dividend Payout and Investment Opportunity}

Investment opportunity as a determinant of dividend policy is in accordance to the agency costs theory. Companies with limited investment opportunities would have greater exposure to agency costs. Thus, to mitigate the principal - agent problems that may arise, these companies will pay higher dividends to shareholders as compared to their counterparts with greater investment opportunities (Jensen, 1986). Prior studies have reported a significantly negative relationship between investment opportunity and dividend payout policy (Abor and Bopkin, 2010; Amidu and Abor, 2006; Khan and Ahmad, 2017). However, Yong and Mustapha (2016), Issa (2015) and Imran (2011) report a positive effect of investment opportunities on dividend payout. Nevertheless, previous studies have also reported that investment opportunity is an insignificant factor to determine the dividend policy (Naceur et al., 2006 and Kowalewski et al., 2008). This research aims to determine whether there is an influence of investment opportunity on the dividend payout ratio. Thus, the following hypothesis is suggested:

H2: Investment opportunity has a significant effect on dividend payout.

\section{Dividend Payout and Profitability}

Another important factor affecting the dividend policy is a company's profitability. According to Fitri et al. (2016), a company's profitability may influence its dividend payments because dividends are part of the company's net income. A study by Issa (2015) finds that profitability has a significant positive correlation with DPR. In addition, Mazengo and Mwaifyusi (2021) and Awad (2019) also report that profitability has a significant positive relationship with dividend payments. Trang (2012) finds that profitability is the most important determinant of Vietnamese companies' dividend policy. Other studies have reported conflicting results. For example, Putri and Ugut (2021), Hashim (2017) and Tamrin 
et al. (2018) argue that profitability has a significant negative effect on the dividend policy. Furthermore, there are previous studies which report there is no relationship between profitability and DPR (Yong and Mustapha, 2016; Hellstrom and Inagambaev, 2012 and Banarjee, 2017). Thus, because of the mixed results from prior research, this study proposes the following hypothesis:

H3: Profitability has a significant effect on the dividend payout.

\section{Dividend Payout and Leverage}

Leverage refers to the used of debt to finance assets and generate potential investment returns on risky sources of funds. The higher the leverage ratios, the more debt the company is using thus, the higher the financial risk faced by the company. Widyasti and Putri (2021) find that the leverage ratio has a significant negative relationship to the company's dividend payments. Their finding is consistent with Tariq (2018). Meanwhile, based on studies done by Yong and Mustapha (2016), Hashim (2017) and Ong et al. (2018) who study on Malaysian listed companies, argue that leverage has no significant effect on the dividend policy. Their results are supported by Putri and Ugut (2021), Olarewaju et al. (2019), Hellstrom and Inagambaev (2012) and Dewasiri et al. (2018) who also reported that leverage is an insignificant factor to determine the dividend payments. This study will examine whether this correlation exists in the Malaysian stock market. The next hypothesis this study put forward is as follows:

H4: Leverage has a significant effect on the dividend payout.

\section{Dividend Payout and Company Size}

Mehta (2012) states that bigger companies' dividend payments are larger as compared to dividend payments make by the smaller size companies. Yong and Mustapha (2016) and Awad (2019) also find that size has a positive significant effect on dividend payout. However, Hellstrom and Inagambaev (2012) report contradictory results. They find that size is an important factor to determine the medium-capitalization companies' DPR. On the other hand, their finding also denotes that size has no significant relationship with largecapitalization companies' dividend policy. Susanto and Tirok (2013), Hashim (2017) and Trang (2012) assert that size is not significant in determining the companies' dividend policy. Since there are contradict results on the effect of company size on the dividend policy from previous research, this study proposes the following hypothesis:

H5: Company size has a significant effect on dividend payout.

Based on the literature review, the conceptual framework of this study can be presented as follows: 
Figure 1 Conceptual Framework

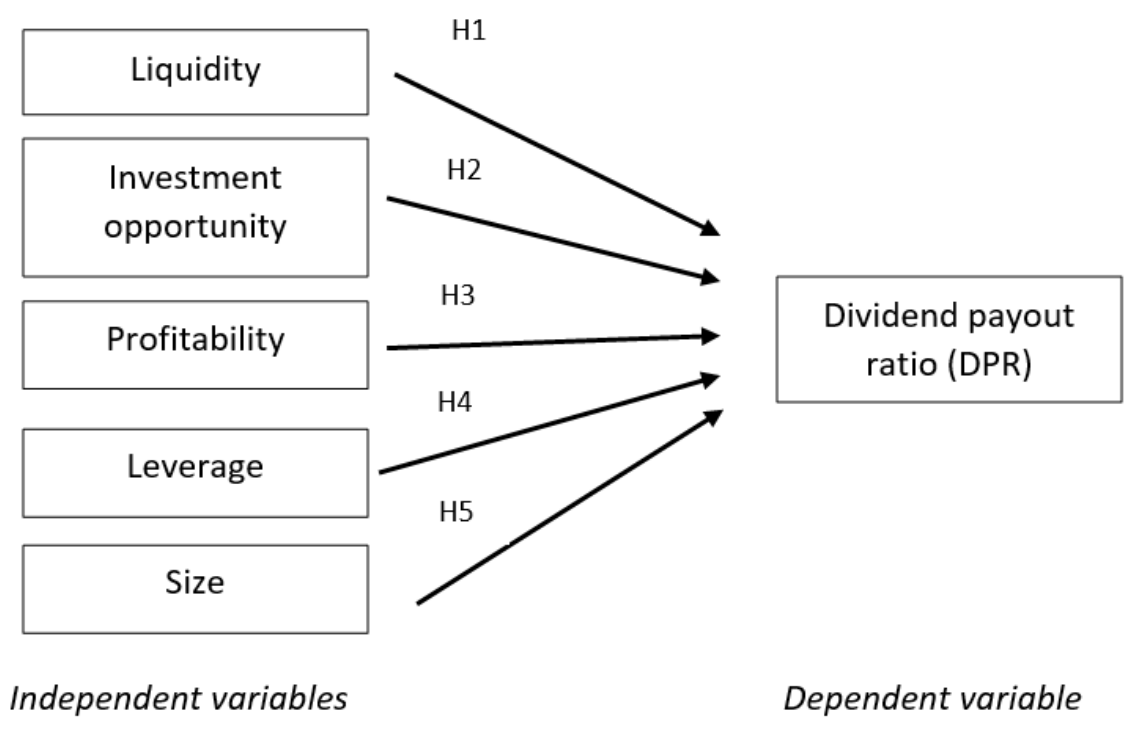

\section{Methodology \\ Data Collection}

The study focused on companies listed on the Bursa Malaysia healthcare sector. The study uses financial data that were taken from the Eikon data stream and also from the companies' annual reports which can be accessed from Bursa Malaysia's website. This study gathers all the information regarding variables that are employed for a period of 10 years from 2010 until 2019. There are 14 companies listed under the healthcare sector on the main market of Bursa Malaysia. However, due to the unavailability of a complete set of data for the whole period of study, only 7 companies are included in this study. Thus, the study contains 70 company-year observations.

The dependant variable in this study is the dividend payout ratio and the independent variables consists of company characteristics namely; liquidity, investment opportunity, profitability, leverage and company size. The variables are measures as follows: 
Table 1. The Measurement of the Variables

\begin{tabular}{|c|c|c|}
\hline Variables & Proxy \& measurement & References \\
\hline $\begin{array}{l}\text { Dependant variable: } \\
\text { Dividend payout }\end{array}$ & $\begin{array}{l}\text { Dividend payout ratio (DPR) } \\
\text { DPR }=\frac{\text { dividend per share }}{\text { net profit per share }}\end{array}$ & $\begin{array}{l}\text { 1. Khan (2020) } \\
\text { 2. Kaźmierska-Jóźwiaka' (2015) } \\
\text { 3. Widyati and Putri (2021) } \\
\text { 4. Mehta (2012) } \\
\text { 5. Ong et.al (2018) } \\
\text { 6. Chakraborty et.al (2018) }\end{array}$ \\
\hline $\begin{array}{l}\text { Independent } \\
\text { variables: } \\
\text { Liquidity }\end{array}$ & $\begin{array}{l}\text { Current ratio }(\mathrm{CR}) \\
\mathrm{CR}=\frac{\text { current assets }}{\text { current liabilities }}\end{array}$ & $\begin{array}{l}\text { 1. Yong and Mustapha (2016) } \\
\text { 2. Banarjee (2017) } \\
\text { 3. Thirumagal and Vasantha (2017) }\end{array}$ \\
\hline $\begin{array}{l}\text { Investment } \\
\text { opportunity }\end{array}$ & $\begin{array}{l}\text { Price-to-book value ratio (PBV) } \\
\text { PBV }=\frac{\text { market price per share }}{\text { book value per share }}\end{array}$ & $\begin{array}{l}\text { 1. Issa (2015) } \\
\text { 2. Amidu and Abor (2006) }\end{array}$ \\
\hline Profitability & $\begin{array}{l}\text { Return on equity (ROE) } \\
\text { ROE }=\frac{\text { net income }}{\text { total equity }}\end{array}$ & $\begin{array}{l}\text { 1. Hellstrom and Inagambaev (2012) } \\
\text { 2. Imran (2011) }\end{array}$ \\
\hline Leverage & $\begin{array}{l}\text { Debt to equity ratio (DER) } \\
\text { DER }=\frac{\text { total debt }}{\text { total equity }}\end{array}$ & $\begin{array}{l}\text { 1. Al-Malkawi (2007) } \\
\text { 2. Abor and Bokpin (2010) } \\
\text { 3. Patra et. al (2012) } \\
\text { 4. Dewasiri et. al (2018) }\end{array}$ \\
\hline Company size & $\begin{array}{l}\text { Natural log value of total assets } \\
\text { (InSIZE) }\end{array}$ & $\begin{array}{l}\text { 1. Mazengo and Mwaifyusi (2021) } \\
\text { 2. Mehta (2012) }\end{array}$ \\
\hline
\end{tabular}

The collected data were analysed using Eviews statistics. A multiple regression analysis was performed to find the effect of the selected company characteristics on the dividend policy of Malaysian healthcare companies. The regression model expressing the linear relation of the independent variables on DPR can be modeled as follows:

$D P R=\beta 0+\beta 1 C R+\beta 2 P B V+\beta 3 R O E+\beta 4 D E R+\beta 5 \operatorname{InSIZE}+\varepsilon$

Where $\beta 0$ denotes the intercept of the regression equation, and $\beta 1, \beta 2, \beta 3, \beta 4$, and $\beta 5$ are the regression coefficients of liquidity, investment opportunity, profitability, leverage, and company size.

\section{Analytical Procedures}

The collected data were analysed using Eviews statistics. This study employed correlation analysis to determine the relationship between the variables. In addition, multiple regression analysis was conducted to gauge the effect of the independent variables (liquidity, investment opportunity, profitability, leverage and size) on the dependent variable (dividend payout). 


\section{Data Analysis and Results \\ Descriptive Statistics}

This section presents empirical analysis of results of the study. Table 2 highlights the summary of descriptive statistics for the dependent and independent variables for the sample of companies. It shows that dividend payout ratio (DPR) has an average value equals to 19.9855 and a standard deviation of 21.6727. The highest DPR is 60.1600 and the lowest is 0.0000 . Current ratio (CR) has an average value of 2.6530. Its standard deviation is 1.3174 , while the maximum CR is 5.8900 and the lowest CR is 0.5600 . Next, the average price to book ratio (PBV) is 2.9546, and its standard deviation is 2.2086 . The value for PBV is ranging from 12.6800 to 0.6100 . For return on equity (ROE), which is measured by net income divided by total equity, the mean is reported at 0.1586 and the value range from 0.0590 to 0.4037 . The standard deviation for ROE is 0.0795 . The mean value for debt to equity ratio (DER) is 0.5714 and its range of value is from the minimum value of 0.0008 to the maximum value of 2.8074 . The standard deviation for DER is 0.5311 . The mean value for SIZE measured Ln (Total Asset) is 9.8059 and standard deviation is 4.5701 . The range of value for SIZE is from the minimum value of 5.2807 to the maximum value of 20.1840 .

Table 2. Summary of Descriptive Analysis

\begin{tabular}{|c|c|c|c|c|c|c|}
\hline & DPR & CR & PBV & ROE & DER & InSIZE \\
\hline Mean & 19.9855 & 2.6530 & 2.9546 & 0.1586 & 0.5714 & 9.8059 \\
\hline Median & 0.9420 & 2.6050 & 2.3300 & 0.1430 & 0.3575 & 7.7496 \\
\hline Maximum & 60.1600 & 5.8900 & 12.6800 & 0.4037 & 2.8074 & 20.1840 \\
\hline Minimum & 0.0000 & 0.5600 & 0.6100 & 0.0590 & 0.0008 & 5.2807 \\
\hline Std. Dev & 21.6727 & 1.3174 & 2.2086 & 0.0795 & 0.5311 & 4.5701 \\
\hline Observations & 70 & 70 & 70 & 70 & 70 & 70 \\
\hline
\end{tabular}

\section{Correlation Analysis}

In order to investigate the linear relationship between the variables, the study used Pearson's correlation coefficient. As showed in Table 3, dividend payout is significantly positively correlated with investment opportunity and profitability. Furthermore, the correlation analysis also showed that dividend payout and liquidity are negatively correlated. Another variables, which are profitability and company size indicate no significant correlation with dividend payout. The strongest correlation is extracted from the correlation of PBV towards ROE (0.6571).

Table 3. Pearson Correlation Analysis

\begin{tabular}{|l|c|c|c|c|c|c|}
\hline & DPR & CR & PBV & ROE & DER & InSIZE \\
\hline DPR & 1.0000 & & & & & \\
\hline CR & $-0.3059^{* *}$ & 1.0000 & & & & \\
\hline PBV & $0.4392^{* *}$ & $-0.3820^{* *}$ & 1.0000 & & & \\
\hline ROE & $0.2549 *$ & -0.1590 & $0.6571^{* *}$ & 1.0000 & & \\
\hline DER & 0.0310 & $-0.6721^{* *}$ & $0.4321^{* *}$ & 0.1425 & 1.0000 & \\
\hline InSIZE & 0.1492 & 0.1735 & $-0.3155^{* *}$ & $-0.3005^{*}$ & -0.1537 & 1.0000 \\
\hline
\end{tabular}

Notes: ${ }^{* *} \mathrm{p}<0.01,{ }^{*} \mathrm{p}<0.05$ 


\section{Regression Analysis}

In the current study, multiple regression analysis was performed in order to evaluate the effect of the independent variables on the dependent variable. Table 4 presents the outcomes of multiple regression analysis performed with DPR as the dependent variable and $\mathrm{CR}, \mathrm{PBV}, \mathrm{ROE}, \mathrm{DER}$ and InSIZE as the independent variables.

From the Table 4, all the independent variables show a centred VIF ranging from 1.14 to 2.27 which denotes that there is no multicollinearity problem exist. The auto-correlation test shows the value is 0.4479 which is more than $5 \%$ significance level, thus the model has no serial correlation. Next, the $p$-value for the heteroskedasticity test, is 0.1315 which is more than $5 \%$ level of significance and thus has a constant variance. The study conducted the Jarque-Bera test to examine the normality of data used. Based on the results we fail to reject null hypothesis ( $p>0.001$ ) hence residuals are normally distributed. In addition, the skewness (0.0210) in this test is acceptable (George and Mallery, 2010) and the kurtosis (3.3230) is also acceptable (Hair et al., 2010).

In view of the outcomes appeared in Table 4, the adjusted R square is 0.3879 . It shows that the independent variables were able to explain $38.79 \%$ variation in the healthcare companies' DPR. While the remaining $61.21 \%$ is explained by other aspects not included in the model. In addition, the significant $F$-ratio $(F=9.744359, p<0.001)$ suggests that the combination of independent variables significantly predicted the dependent variable. Multiple regression analysis showed that four predictors have a significant effect on the healthcare companies' payout ratio.

Table 4. OLS Regression Model Results

\begin{tabular}{|l|c|c|c|c|}
\hline & Coefficient & $t$-Statistic & Prob. & Centred VIF \\
\hline Constant & 20.77627 & 1.920583 & 0.0592 & \\
\hline CR & -7.674337 & -3.625707 & $0.0006^{*}$ & 1.866005 \\
\hline PBV & 5.987473 & 4.296425 & $0.0001^{*}$ & 2.273452 \\
\hline ROE & -13.88372 & -0.394601 & 0.6944 & 1.875429 \\
\hline DER & -19.90677 & -3.658183 & $0.0005^{*}$ & 2.004859 \\
\hline InSIZE & 1.576160 & 3.309625 & $0.0015^{*}$ & 1.136772 \\
\hline F-statistic & $9.744359^{* *}$ & & \\
R $^{2}$ & 0.432230 & & & \\
Adjusted R & 0.387873 & & & \\
Auto-correlation test & 0.4479 & & \\
Heteroskedasticity test: White & 0.1315 & & & \\
Jarque-Bera test & 0.3093 & & & \\
Skewness & 0.0210 & & & \\
Kurtosis & 3.3230 & & & \\
\hline
\end{tabular}

Notes: ${ }^{* *} \mathrm{p}<0.01, * \mathrm{p}<0.05$

The variable CR $(\beta=-7.674, p<0.05)$ was seen to be significantly negative with $D P R$, thus $\mathrm{H} 1$ is supported. Therefore, this suggests that liquidity is an important factor in predicting the companies' dividend payments. Our finding supports previous findings in the literature (Banarjee, 2017; Mehar, 2002). The results also reveal that PBV $(\beta=5.987, p<0.05)$ has a significant positive relationship with DPR. This finding is in line with study done by Yong and Mustapha (2016), Issa (2015) and Imran (2011). Therefore, H2 is also supported. From the Table 4, it illustrates that DER $(\beta=-19.907, p<0.05)$ possess a significant negative relationship 
with the DPR of Malayian healthcare companies. Therefore, $\mathrm{H} 4$ is supported. This implies that a company with higher leverage ratio would pay lower dividends to its shareholders. Our result is consistent with the previous study by Widyasti and Putri (2021); Tariq (2018); Okoro et. al (2018); Arko et. al (2014). The natural loan of total assets treats as a proxy for company size. The results also reveal that InSIZE $(\beta=1.576, p<0.05)$ positively affects DPR. Thus, H5 is supported. This indicates that a larger company would pay higher dividends. Our finding shows the same results with the study done by Mehta (2012) and Yong and Mustapha (2016).

Despite the fact that Issa (2015); Awad (2019) reported a significant positive association between profitability and dividend payout, we find that $\operatorname{ROE}(\beta=-13.883, p>0.05)$ has an insignificant relationship with DPR. Thus, H3 is not supported. This finding supports previous findings in the literature (Yong and Mustapha, 2016; Hellstrom and Inagambaev, 2012; Banarjee, 2017).

\section{Conclusion}

This study aims to empirically investigate the influence of five independent variables namely; liquidity, investment opportunity, profitability, leverage and company size on dividend policy of healthcare companies listed on the main board of Bursa Malaysia. The period under study is 10 years; from 2010 until 2019 and the multiple regression analysis was utilised to capture the relationship. The results reveal that liquidity and leverage have a significant negative relationship to DPR. In addition, investment opportunity and company size show a significant positive relationship towards DPR. Profitability is negatively correlated with DPR although it is not statistically significant.

In light with these findings, it is worthwhile for the investors to consider the companies in the healthcare sector for the investment purpose. These findings also add to a growing body of literature on dividend policy in the context of the Malaysia healthcare sector. Future study on this field may identify and include more variables that influence DPR.

\section{Acknowledgement}

We would like to express our sincere appreciation and gratitude to Bahagian Penyelidikan, Jaringan Industri \& Alumni (BPJIA) of UITM Cawangan Johor. Because of their support, finally we are able to complete this research paper.

\section{Corresponding Author}

Ruziah A. Latif

Universiti Teknologi MARA, Malaysia

Email: ruzia418@uitm.edu.my

\section{References}

Abor, J., \& Bokpin, G. A. (2010). Investment opportunities, corporate finance, and dividend payout policy: Evidence from emerging markets. Studies in Economics and Finance, 27 (3), 180-194.

Afza, T., \& Nazir, M. S. (2008). Working capital approaches and firm's returns in Pakistan. Pakistan Journal of Commerce and Social Sciences, 1, 25-36.

Al Sawalqa, F. A. (2021). Life-cycle theory of corporate dividend policy in Jordan: The role of equities, assets, and age during the period 2015-2019. The Journal of Asian Finance, Economics and Business, 8(6), 1-11. 
Al-Twaijry, A. A. (2007). Dividend policy and payout ratio: evidence from the Kuala Lumpur stock exchange. Journal of Risk Finance, 8(4), 349-363.

Amidu, M., \& Abor, J. (2006). Determinants of dividend payout ratios in Ghana. Journal of Risk Finance, $7(2), 136-145$.

Arko, A. C., Abor, J. Y., Adjasi, C. K. D., \& Amidu, M. (2014). What influence dividend decisions of firms in Sub-Saharan African? Journal of Accounting in Emerging Economies, 4(1), 57-78.

Awad, B. (2015). Determinants of dividend policy in Kuwait Stock Exchange. International Journal of Business and Management Review, 3(9), 72-78.

Banerjee, S. (2017). Determinants of dividend policy of listed information technology companies in India. SCMS Journal of Indian Management, 14(3), 54-63.

Chakraborty, S., Shenoy, S. S., \& Kumar, S. N. (2018). Empirical evidence on the determinants of dividend pay-outs in the auto components sector in India. Investment Management and Financial Innovations, 15(4), 356-366.

Danila, N., Noreen, U., Azizan, N. A., \& Farid, M. (2020). Growth opportunities, capital structure and dividend policy in emerging market: Indonesia case of study. Journal of Asian Finance Economics and Business, 7(10), 1-8.

DeAngelo, H., DeAngelo, L., \& Skinner, D. (2004). Are dividends disappearing? Dividend concentration and the consolidation of earnings. Journal of Financial Economics, 72, 425-456.

Dewasiri, N. J., Yatiwelle Koralalage, W. B., Abdul Azeez, A., Jayarathne, P. G. S. A., Kuruppuarachchi, D., \& Weerasinghe, V. A. (2019). Determinants of dividend policy: evidence from an emerging and developing market. Managerial Finance, 45(3), 413429.

Farre-Mensa, J., Michaely, R., \& Schmalz, M. C. (2014). Payout policy. Annual Review of Financial Economics, 6, 75-134.

Fitri, R. R., Hosen, M. N., \& Muhari, S. (2016). Analysis of factors that impact dividend payout ratio on listed companies at Jakarta Islamic Index. International Journal of Academic Research in Accounting, Finance and Management Sciences, 6(2), 87-97.

George, D., \& Mallery, M. (2010). SPSS for Windows Step by Step: A Simple Guide and Reference, (10th Ed.) Boston: Pearson Education.

Gordon, M. J. (1959). Dividends, earnings, and stock prices. The Review of Economics and Statistics, 99-105.

Hair, J. F., Black, W., Babin, B. J., \& Anderson, R. (2010). Multivariate Data Analysis (7th Ed.). Upper Saddle River, NJ: Pearson

Hashim, S. L. M. (2017). Analysis on dividend payout: Empirical evidence of property companies in Malaysia. International Journal of Industrial Management, 3, 61-71.

Hellstrom, G., \& Inagambaev, G. (2012). Determinants of dividend payout ratios A study of Swedish large and medium caps. Umea School of Business \& Economics, 1-77.

Ho, H. (2003). Dividend policies in Australia and Japan. International Advances in Economic Research, 9 (2), 91-100.

Imran, K. (2011). Determinants of dividend payout policy: A case of Pakistan engineering sector. The Romanian Economic Journal, 41, 47-60.

Issa, A. I. F. (2015). The determinants of dividend policy: Evidence from Malaysian firms. Research Journal of Finance and Accounting, 6(18), 69-87. 
Jaara, B., Alashhab, H., \& Jaara, O. O. (2018). The determinants of dividend policy for nonfinancial companies in Jordan. Journal of Economics and Financial Issues, 8(2), 198209.

Jensen, M. C. (1986). Agency costs of free cash flows, corporate finance and takeovers. The American Economic Review. 76(2), 323-329.

Kasahara, A., \& Orihara, M. (2021). Family firms' dividend policies: Evidence from a Japanese tax reform. Finance Research Letters, Forthcoming, Available at SSRN: https://ssrn.com/abstract $=3858212$

Kaźmierska-Jóźwiak, B. (2015). Determinants of dividend policy: Evidence from Polish listed companies. Procedia Economics and Finance, 23, 473-477.

Khan, F. A., \& Ahmad, N. (2017). Determinants of dividend payout: An empirical study of pharmaceutical companies of Pakistan Stock Exchange. Journal of Financial Studies \& Research, 1-16.

Khan, F. (2020). Firm earning and dividend policy: A case of Malaysian stock market. SSRG International Journal of Economics and Management Studies (SSRG-IJEMS), 7 (1), 145158.

Kowalewski, O., Stetsyuk, I., \& Talavera, O. (2007). Corporate governance and dividend policy in Poland, German Institute for Economic Research.

Lintner, J. (1965). The valuation of risk assets and the selection of risky investments in stock portfolios and capital budgets. The Review of Economics and Statistics, 47(1), 13-37.

Maldajian, C., \& El Khoury, R. M. (2014). Determinants of the dividend policy: An empirical study on the Lebanese Listed Banks. International Journal of Economics and Finance, 6(4), 240-256.

Malik, F., Gul , S. , Khan, M. T., Rehman, S., \& Khan, M. (2013). Factors influencing corporate dividend payout decisions of financial and non-financial firms. Research Journal of Finance and Accounting , 4(1), 35-46.

Manneh, M. A., \& Naser, K. (2015). Determinants of corporate dividends policy: evidence from an emerging economy. International Journal of Economics and Finance, 7(7), 229-239.

Mazengo, S. D., \& Mwaifyusi, H. A. (2021). The effect of liquidity, profitability and company size on dividend payout: Evidence from financial institutions listed in Dar Es Salaam Stock Exchange. Business Education Journal, 1(2), 1-12.

Mehar, A. (2003). Corporate governance and dividend policy. MPRA Paper 619. https://mpra.ub.uni-muenchen.de/619/1/MPRA_paper_619.pdf

Mehta, A. (2012). An empirical analysis of determinants of dividend policy: Evidence from the UAE companies. Global Review of Accounting and Finance, 3(1), 18-31.

Miller, M., \& Modigliani, F. (1961). Dividend policy, growth, and the valuation of shares. The Journal of Business, 34, 411.

Naceur, S. B., Goaied, M., \& Belanes, A. (2006). On the determinants and dynamics of dividend policy, International Review of Finance, 6(1-2), 1-23.

Okoro, C. Y., Ezeabasili, V., \& Alajekwu, U. B. (2018). Analysis of the determinants of dividend payout. Annals of Spiru University, 1, 141-166.

Olarewaju, O. M., Migiro, S. O., \& Sibanda, M. (2019). Examining bank-specific determinants of the dividend payout ratio of Sub-Saharan Africa banks: The panel GMM approach. Afro-Asian Journal of Finance and Accounting, 9(1), 40-59.

Ong C. L., Thaker, H.M.T., Khaliq, A., \& Thaker, M. A. M. T. (2018). The determinants of dividend payout: Evidence from the Malaysian property market. Iqtishadia, 11(1), 2746. 
Patra, S., Poshakwale, T., \& Ow-Yeong, K. (2012). Determinants of corporate dividend policy in Greece. Applied Financial Economics, 22(13), 1079-1087.

Putri, C. C. P., \& Ugut, G. S. S. (2021). Factors affecting dividend payout ratio in LQ-45 (nonbanking) companies listed in Indonesia Stock Exchange, 2011-2019. Enrichment: Journal of Management, 11(2), 225-230.

Setiawan, D. E., \& Rahmawati, I. Y. (2020). The Effect of Liquidity, Profitability, Leverage on Corporate Value with dividend policy and bi rate as moderated variables (Study of banking companies listed on the Indonesia Stock Exchange in 2014-2017. Economics and Business Solutions Journal, 4(1), 1-19.

Suji, T. (2010). What are the determinants of dividend policy?. Business and Economics Journal, 9(5), 188-500.

Susanto, A., \& Tirok, J. (1387). Dividend payout ratio: Factors that affect it, and subsequent earning growth. Journal of Applied Finance and Accounting, 6(1), 97-111.

Tamrin, M., Mus, H. R., \& Arfah, A. (2018). Effect of profitability and dividend policy on corporate governance and firm value: Evidence from the Indonesian manufacturing sectors. IOSR Journal of Business and Management (IOSR-JBM), 19(10), 66-74.

Tariq, A. (2018). The joint-determinants of leverage and dividend policy: A balanced panel study of non financial firms of India and Pakistan. Germany: European Scientific Journal, 11(10), 311-324.

Thirumagal, P. G., \& Vasantha, S. (2017). Dividend payout determinants: Evidence from Indian Industries. International Journal of Pure and Applied Mathematics, 117(21), 811-829.

Trang, N. T. X. (2012). Determinants of dividend policy: The case of Vietnam. International Journal of Business, Economics and Law, 1, 48-57.

Widyasti, I. G. A. V., \& Putri, I. G. A. M. A. D. (2021). The Effect of Profitability, Liquidity, Leverage, Free Cash Flow, and Good Corporate Governance on Dividend Policies (Empirical Study on Manufacturing Companies Listed in Indonesia Stock Exchange 2017-2019). American Journal of Humanities and Social Sciences Research, 5(1), 269278.

Yong, T. M., \& Mustapha, M. (2016). Determinants of dividend payout ratio: Evidence from Malaysian public listed firms. Journal of Applied Environmental and Biological Sciences, 6(15), 48-54.

Yusof, Y., \& Ismail, S. (2016). Determinants of dividend policy of public listed companies in Malaysia. Review of International Business and Strategy, 26 (1),88 -99. 